\title{
Characterization and ecological role of free-living nitrogen -fixing bacteria isolated from the rhizoplane of Melastoma malabathricum inhabiting acidic plain lands in Kalimantan
}

\author{
Yasuyuki Hashidoko ${ }^{1}$, Yukako Gotou ${ }^{1}$, Mitsuru Osaki ${ }^{1}$, Erry Purnomo ${ }^{2}$, Limin H. Suwido ${ }^{3}$ and Satoshi Tahara ${ }^{1}$ \\ Graduate School of Agriculture, Hokkaido University, Sapporo 060-8589, Japan. \\ Tel: +81-11-706-3839. Fax: +81-11-706-4182. E-mail: yasu-h@abs.agr.hokudai.ac.jp \\ Center for Tropical Acid Soil Studies, Faculty of Agriculture, UNLAM, PO Box 1028 Banjarbaru, South Kalimantan 70714, Indonesia. \\ Faculty of Agriculture, The University of Palangkaraya, Palangkaraya, Central Kalimantan, Indonesia.
}

\begin{abstract}
The rhizoplane microorganisms of Melastoma malabathricum, distributing throughout the acid sulfate and peat soils of South Kalimantan, Indonesia, were investigated, using a soft gel media of $\mathrm{N}$-free Winogradsky's mineral solution solidified with $0.3 \%$ gellan gum. Two bacteria, Sphingomonas rosa EC-K013 and Burkholderia cepacia EC-K014 belonging to the subclasses of $\alpha$ - and $\beta$-Proteobacteria, respectively, emerged in the nitrogen-free medium. Inoculation of $S$. rosa EC-K013 in the $M$. malabathricum seedlings grown in $\mathrm{N}$-free, 1/4 Hoagland's No. 2 medium (pH 3.0) resulted in better growth of the seedlings. In the soft gel medium, EC-K013 also stimulated the growth of a root-associating fungus, tentatively identified as Nectria sp. and a nitrogen-fixer, Mesorhizobium sp., suggesting that $S$. rosa plays an important role in promotion of microfloral devlopment around the rhizosphere of some acidic soil-adapting plants.
\end{abstract}

Key words: Acid-sulfate soil, Burkholderia cepacia, Melastoma malabathricum, Rhizoplane bacterium, Sphingomonas rosa.

Many species of genus Melastoma, such as $M$. malabathricum L., are known to be Al-accumulators (Watanabe et al., 1998a), and the adaptability of Melastoma spp. to very low $\mathrm{pH}$ acid-sulfate soils is mainly due to this property. M. malabathricum, distributing throughout Central and South Kalimantans, Indonesia, is a powerful pioneer shrub tree that is able to spread throughout the acid-sulfate soil regions. Since acid-sulfate soil with very low $\mathrm{pH}$ (2.5-3.5) has undergone strong leaching, such acid-tolerable plants must employ certain strategies to get nutrients, including $\mathrm{N}$ and P. Melastoma spp. are also known as ammonia-assimilating plants, preferring $\mathrm{NH}_{4}^{+}$ rather than $\mathrm{NO}_{3}{ }^{-}$as a nitrogen source (Watanabe et al., 1998b). Bearing these facts in mind, the presence of free -living nitrogen-fixing bacteria on the rhizoplane of $M$. malabathricum is thought to be beneficial to their survival in acid-sulfate soils, due to the release of ammonia into the rhizosphere. Ammonia is very likely a key material in the adaptation of the M. malabathricum to acid-sulfate soil, not only as a nitrogen source but also as an inorganic base provided via nitrogen-fixation. So far during our field investigation in South and Central Kalimantan, free -living nitrogen-fixing, and/or $\mathrm{pH}$-maitaining bacteria were frequently isolated from the rhizosphere of $M$. malabathricum. In this paper, we report an effective growth promotiing activity of a sphingomonad from the rhizosphere toward the seedlings under N-starving and strongly acidic conditions to discuss further its ecological role in forming a tripartite with a nitrogen-fixer and a root-associating fungus.

\section{MATERIALS AND METHODS}

Screening and identification of rhizoplane bacteria We used a gellan gum-base soft gel medium for the observation and evaluation of the microflora of rhizoplane nitrogen-fixing bacteria as described in our paper (Hashidoko et al., 2002). Bacteria obtained from root washings were purified on modified Winogradsky's medium (Winogradsky's mineral mixture, 0.5\% mannitol, $0.005 \%$ yeast extract and $2 \%$ agarose). For identification, 16S rRNA gene sequences were determined and homology searches conducted using the DDBJ BLASTN DNA database (http://www.ddbj.nig.ac.jp/E -mail/homology-j.html). All of the DNA template for PCR amplification of the $16 \mathrm{~S}$ rRNA gene regions was prepared using Isoplant II DNA extraction kit (Wako Pure Chemical Industries, Osaka, Japan). For DNA amplification, we used the PCR kit Gene Taq (Nippon Gene, Toyama, Japan) or HotStarTaq (Quiagen, Valencia, USA) according to its instruction protocol. The amplified 
DNA fragments were directly sequenced using the BigDye $^{\circledR}$ Terminator v3.1 Cycle Sequencing Kit (Applied Biosystems, Foster City, USA) with several sequencing primers under the following conditions: 1 cycle at $96^{\circ} \mathrm{C}$ for $2 \mathrm{~min}$ and 25 cycles of $96^{\circ} \mathrm{C}$ for $30 \mathrm{~s}, 50^{\circ} \mathrm{C}$ for $15 \mathrm{~s}, 60^{\circ} \mathrm{C}$ for 4 min by using the ABI PRISM ${ }^{\circledR} 310$ Genetic Analyzer (Applied Biosystems). The resultant DNA sequences were assembled and then searched for homology on the BLASTN searching system on a DNA database.

\section{Identification of rhizosphere fungi}

Fungi were identified by means of partial sequence determination of $5.8 \mathrm{~S}$ and 18S rRNA genes and the ITS regions between them. After the chromosomal DNA was obtained, ITS regions were amplified with PCR using the ITS1 forward (5'-TCCCGTAGGTGAACCTGCGC-3') and ITS4 reverse (5'-TCCTCCGCTTATTGATATGC-3') primers that are specific for eukaryotic microorganisms and give rise to a $450 \mathrm{bp}$ PCR product (Kretzer \& Bruns, 1999; Sugita \& Nishikawa, 2003). The fungal mycelium growing on the PD agar plate was inoculated to new PD agar plate and incubated at $23^{\circ} \mathrm{C}$ for $3-7$ days, and the myceria on the plate was directly scraped with a loop and then inoculated separately or together with $S$. rosa EC -K013 to the N-free soft gel medium. DNA sequence determination followed by its homology search was performed as described above for bacetria.

\section{Seedling preparations and inoculation assay}

M. malabathricum used for microfloral investigation in the rhizoplane were collected from the ridge of a sulfate acid soil paddock at Serapatbaru in Southern Kalimantan, and from the ridge of a peat soil field at Kalampangan in Central Kalimantan, respectively. For plant growth, we used an EYELA LTI 600 SD thermo-controlling incubator equipped with red and blue light emitting diodes (EYELA LED-red/blue, 40/10 per board of $30 \times 30 \mathrm{~cm}^{2}$ width) as illuminants. A bed volume of $50 \mathrm{ml}$ vermiculite was poured into a tall-skirted Petri dish, and moistened with approximately $30 \mathrm{ml}$ of a $\mathrm{N}$-free 1/4 Hoagland's no. 2 solution, in which molybdenum trioxide $\left(\mathrm{MoO}_{3}\right)$ was enhanced 50-fold and adjusted to $\mathrm{pH}$ 3.0.

Seeds collected from Central Kalimantan were sown in the autoclaved vermiculite bed moistened with the sterile $\mathrm{N}$-free $1 / 4$ Hoagland's no. 2 as described above, and incubated at $23^{\circ} \mathrm{C}$ under a $16-\mathrm{h}$ light/8-h dark photoperiod. The $M$. malabathricum seedlings were prepared as follows: after the $50 \mathrm{ml}$ vermiculite beds (wetted with the N-free 1/4 Hoagland's no. 2 medium, $\mathrm{pH}$ 3.0) were autoclaved, five M. malabathricum seedlings grown for 4 weeks on another vermiculite bed (wetted with the same N-free 1/4 Hoagland's no. 2 medium with pH 5.5) were briefly rinsed with $70 \%$ ethanol, then washed with sterile water, then transplanted. The seedlings were inoculated with, $S$. rosa (approximately $1 \times 10^{5}$ cells), $B$. cepacia ( $1 \times 10^{5}$ cells), $S$. rosa plus B. cepacia (both $1 \times 10^{5}$ cells) and a control (sterile water). Bacteria grown on an agar plate of modified Winogradsky's medium (containing 0.5\% mannitol and $0.005 \%$ yeast extract) were scraped with a loop, suspended in $5 \mathrm{ml}$ sterile water and used as inoculants. The seedlings ( $S$. rosa-inoculated, B. cepacia -inoculated, $S$. rosa plus $B$. cepacia-inoculated and the control) were grown under the same conditions for 8 weeks to see the effects of the bacterial inoculation on seedling growth under $\mathrm{N}$-deficient conditions.

\section{Recovery of rhizoplane microorganisms from $M$.} malabathricum seedlings used for inoculation assay

The 8-week-grown seedlings harvested were carefully removed vermiculites from the roots under aseptic conditions, and put them on a plain agar plate to adhere to the gel surface. After 1 day-incubation on the plate, the plants were removed. The resulting agar plate was further incubated at $25^{\circ} \mathrm{C}$ for 7 days. Mucilaginous, bacterial colony-like small plaques on the plate emerged after the incubation were then spread over MW agar and PD agar plates. Microorganisms grown on these plates were routinely isolated and characterized by determining 16S rRNA gene for prokaryotes and ITS-18S rRNA region for eukaryotes using ITS1 and ITS4 primers (Gardes \& Bruns, 1993).

\section{RESULTS AND DISCUSSION}

\section{Bacterial Isolates and Their Physiological Properties}

We initially investigated microorganisms that comprise the rhizoplane microflora, particularly targetting nitrogen -fixing bacteria. Hence, $\mathrm{N}$-free soft gel medium was used for trapping and observation of the root-associating nitrogen-fixing bacteria. This method was first developed by the Brazilian microbiologist Dobereiner and her coworkers in 1980 (Dobereiner, 1995), but we replaced the $0.2 \%$ agarose gel matrix with $0.3 \%$ gellan gum. As shown in Fig. 1, gellan gum was highly transparent, so even thin or highly transparent colonies are visible through the glass tube (Hashidoko et al., 2002).

Two rhizoplane bacteria (strains EC-K013 and EC-K014) were isolated from a specimen of $M$. malabathricum grown along an edge of an acid-sulfate 


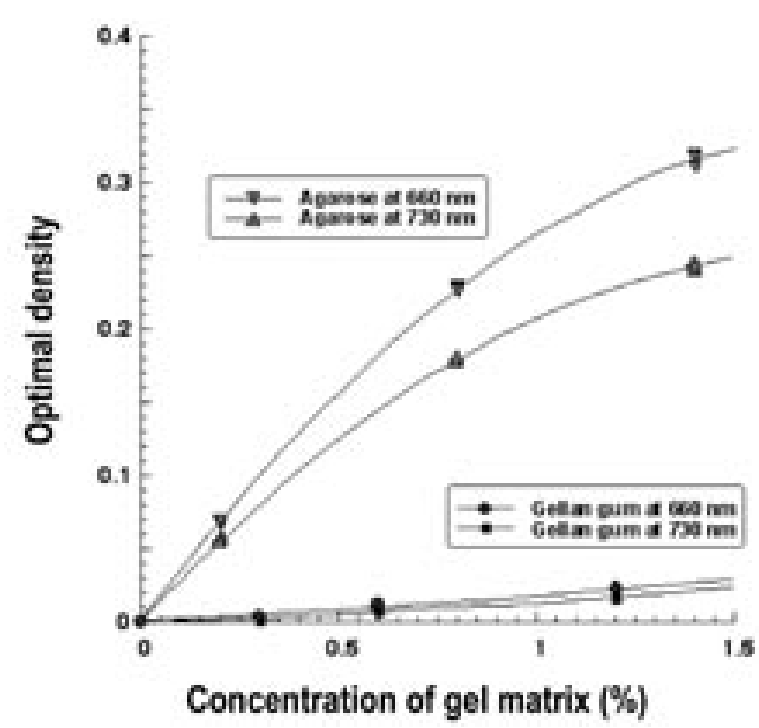

Fig. 1. Transparency of gellan gum in comparison with agarose

Winogradsky's mineral solution ( $\mathrm{pH}$ 6.0) was solidified with gellan gum or highly pure agarose in $1 \mathrm{~cm}$-thick polystyrene cuvettes. Optimal density at $660 \mathrm{~nm}$ and $730 \mathrm{~nm}$ were measure in triplication at a gel concentration and avaraged. Each gel matrix was set at three different concentrations.

paddock at Serapatbaru, Southern Kalimantan. Our physiological and 16S rRNA gene determinations led to the identification of Sphingomonas rosa (accession no. $\mathrm{AB} 121233)$ and Burkholderia cepacia (AB121232) for EC -K013 and EC-K014, respectively. The former was nonmotile and highly aggregative, while the latter was highly motile and produced mucilaginous materials around the cells. Another Sphingomonas sp. was also isolated as the major rhizoplane bacterium of a M. malabathricum growing on acid-sulfate clay soil in Paduran, Central Kalimantan. A specimen of $M$. malabathricum grown on peat land at Kalampangan, Central Kalimantan, possessed two Burkholderia species, and one of which was tentatively identified as $B$. brazilensis.

Effect of rhizoplane bacteria inoculation on the growth of $M$. malabathricum seedlings under acidic, $\mathrm{N}$-free conditions

The screening of rhizoplane epiphytes from a specimen of $M$. malabathricum, grown along the ridge of an acidsulfate paddock in South Kalimantan, led to the isolation of two heterotrophic bacteria. By use of physiological properties and 16S rRNA gene determination, the two isolates were identified as $S$. rosa and B. cepacia, both of which are known to be root-associating bacteria (Takeuchi et al., 1995; Poole et al., 2001). In a 0.3\% gellan gum medium, $S$. rosa was non-motile and aggregative, while $B$. cepacia was highly motile.
The test seedlings inoculated with $S$. rosa EC-K013 showed a significantly better growth performance than the control seedlings (Fig. 2). In fact, the seedlings in the control dish showed severe stunting and yellowing, a symptom obviously due to nitrogen-deficiency. In contrast, neither the single-inoculation of $B$. cepacia nor the double-inoculation of $S$. rosa plus B. cepacia showed any positive effect on the seedling growth. This meant that nitrogen-fixation is affected by the combination of bacterial species that compose the rhizospherous microflora.

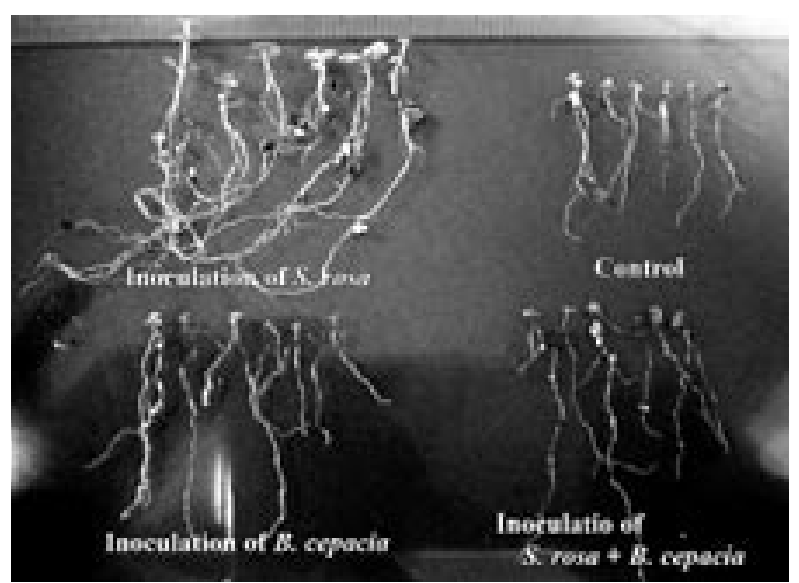

Fig. 2. Growth stimulating effect of Sphingomonas rosa $R-1$ strain after inoculation on Melastoma seedlings grown on $\mathrm{N}$-free medium/vermiculite bed.

The survival frequency of the inocula was also investigated. As shown in Table 1 , both $S$. rosa and $B$. cepacia survived around the rhizosphere and/or rhizoplane; however, their effects on the growth of the seedlings were distinguishable. The growth stimulating properties of $S$. rosa were completely inhibited in the double inoculation of both $S$. rosa and B. cepacia. A specimen of improved rice IR 64 with minimal harvests

Table 1. Survival and effectiveness of the inoculates around the roots of Melastoma seedlings grown in $\mathrm{N}$-free $1 / 4$ Hoagland No. 2 medium.

\begin{tabular}{|c|c|c|c|}
\hline \multirow{2}{*}{ Treatment } & \multirow{2}{*}{$\begin{array}{l}\text { Inecolated } \\
\text { bertemian }\end{array}$} & \multicolumn{2}{|c|}{ Eflectivenens } \\
\hline & & Anial & Tout \\
\hline$S$ mon insculated ( $10^{5}$ cells) & Servized & $H$ & $H$ \\
\hline D. cepocia inoculeted $\left(10^{3}\right.$ cells) & Servived & - & + \\
\hline $\begin{array}{c}\text { 5. rosat R. cepocia inoculated } \\
\text { (10 cells }+10^{6} \text { cells) }\end{array}$ & Beth sarvived & - & + \\
\hline Coctrol (sterilised water) & Neae" & & \\
\hline
\end{tabular}

* None grew in N-free Winogradsky's media, but certain fungus and saprophytic bacterium were apparent in potato-dextrose agar. 
for 4 years in an acidic paddock in Paduran, Central Kalimantan possessed Burkholderia sp. on the rhizoplane but no Sphingomonas sp. This preliminary observation and our experiment using M. malabathricum seedlings described here suggested that these bacterial species occupy different ecological positions in the rhizospherous microflora.

In M. malabathricum seedlings inoculated with S. rosa EC-K013, a fungal development was uniquely observed in rhizosphere of the harvested seedlings (Table 2). This saprophytic fungus that grow well on PD agar plate was tentatively identified as Nectria sp. by sequence determination of ITS-18S rRNA gene region. When $S$. rosa EC-K013 and the accompanying fungus were inoculated together to the N-free soft gel medium, their mix-culture uniquely accelerated growth of nitrogen -fixation of non-nodulation, free-living Mesorhizobium sp. that is slow-growing diazotrophic bacterium. This Mesorhizobium sp. uniquely grew and spread horizontally

Table 2. Rhizoplane microflora of the treated Melastoma seedlings grown in $\mathrm{N}$-free $1 / 4$ Hoagland No. 2 medium

\begin{tabular}{|c|c|c|c|c|}
\hline & \multicolumn{2}{|c|}{ freqeenery hid } & meles- & $m$ \\
\hline Treatuent (after 2-month) & sma & A eoperia & lovelese & $h=p$ \\
\hline Inocelation of $S$, rasa & 1070 & 010 & e10 & 1010 \\
\hline Incculation of $B$. cepacia & 0.10 & 1010 & ero & $1 / 10$ \\
\hline $\begin{array}{l}\text { Inceculation of } \\
\qquad \text { S. resa + E. copacia }\end{array}$ & 47 & $7 / 7$ & an & 07 \\
\hline Contred (sterilined water) & 09 & $2 y^{*}$ & $9.9^{*}$ & 69 \\
\hline
\end{tabular}

Rhizomicrofloral investigation was done with 7 10 replications. ${ }^{\star} \mathrm{B}$. cepacia may be a seed-born bacterium, same as other spontaneous microorganisms. **No growth in MW agar plate was apparent, but it emerged in potato-dextrose medium.

Fig. 3. Emergence of Mesorhizobium sp. in soft gel medium mix-cultured $S$. rosa EC-K013 and Nectria sp.

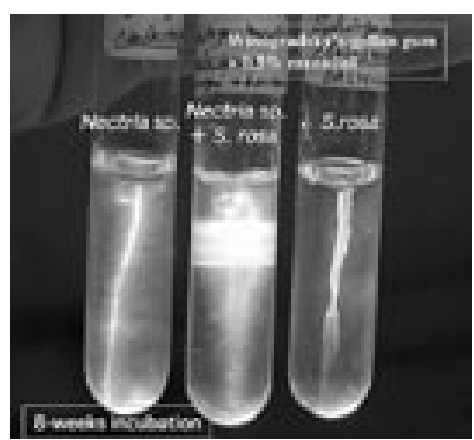

This horizontal colony emergence was observed only when two inoculants were mix-cultured in $\mathrm{N}$-free soft gel medium. This is most likely a tripartite relationships among these three microorganisms. only at appropriate depth of the medium, alike many of micro-aerobic diazotrophs (Fig. 3). Synergstic effect of this rhizo-biocomplex (Hashidoko \& Tahara, 2005) is most likely to function in rhizosphere of the $M$. malabathricum seedlings for effective nitrogen fixation.

When the seedlings grown in vermiculite beds wetted with P-free 1/4 Hoagland's No. 2 (pH 5.5) and $\mathrm{AlPO}_{4}$ powders previously washed with pure water to remove soluble phosphates were preliminarily examined, only the seedlings in the B. cepacia-inoculated rhizoplane dish showed better growth. This preliminary result also suggested a capability of $B$. cepacia to solubilize aluminum phosphate powders in acidic soil.

Our laboratory experiments showed that sulfate acid-tolerable $M$. malabathricum possesses functional rhizoplane microflora on its rhizosphere to cope with nutrient deficiencies under strongly acidic conditions. The rhizospherous microorganisms may affect on rhizosphere conditions and bring benefits to the host plant. As known in flavonoids that play a role in rhizobia -symbiosis as signal compounds of leguminous plants, some non-leguminous plants have a strategy of regulating their rhizoplane microorganisms to deliver their maximal capacity by root exudates (Strong \& Phillips, 2001). In M. malabathricum also, phenolic components in the root exudates stimulated the growth and/or cell aggregation of $S$. rosa in the gellan gum medium (data not shown). Such chemical signals exuded from the rhizophere are likely to be involved in cross-talk signals among the microorganisms that compose the rhizoplane biocomplex in order to maintain host-beneficial rhizosphere environments.

\section{REFERENCES}

Dobereiner, J. 1995. Isolation and identification of aerobic nitrogen-fixing bacteria from soil and plants. In: Methods in Applied Soil Microbiology and Biochemistry. (Alef, K. \& Nannipieri, P. eds.). Pp. 134 -141. Academic Press, London.

Gardes, M. \& Bruns, T. D. 1993. ITS primers with enhanced specificity for basidiomycetes application to the identification of mycorrhizae and rusts. Molecular Ecology 2: 113-118.

Hashidoko, Y., Tada, M., Osaki, M. \& Tahara, S. 2002. Soft gel medium solidified with gellan gum for preliminary screening for root-associating, free -living nitrogen-fixing bacteria inhabiting the rhizoplane of plants. Bioscience, Biotechnology and Biochemistry 66: 2259-2263. 
Hashidoko, Y. \& Tahara, S. 2005. Rhizo-biocomplex: an important concept to regulate rhizospherous environment for sustainable crop production. In Proceedings of International Conference on 'Sustainable Crop Production in Stress Environments: Management and Genetic Options', JNKVV, Jabalpur, India, February 9-12, 2005. (Tomar, V. S. \& Behl, R. S. eds.). Pp. 101-109.

Poole, E. J., Bending, G. D., Whipps, J. M. \& Read, D. J. 2001. Bacteria associated with Pinus sylvestrisLactarius rufus ectomycorrhizas and their effects on mycorrhiza formation in vitro. New Phytologist 151: 743-751.

Strong, D. R. \& Phillips, D. A. 2001. Notes from the underground. Communication and control in the rhizosphere. Plant Physiology 127: 727-730.

Takeuchi, M., Sakane, T., Yanagi, M., Yamasato, K., Hamana, K. \& Yokota, A. 1995. Taxonomic study of bacteria isolated from plants: proposal of Shingomonas rosa sp. nov., Sphingomonas pruni sp. nov., Sphingomonas asaccharolytica sp. nov., and Sphingomonas mali sp. nov. International Journal of Systematic Bacteriology 45: 334-341.

Tchan, Y.-T. \& New, P. B. 1984. Genus 1. Azotobacter Beijerinck 1907, 567. ${ }^{\mathrm{AL}}$ In Bergey's Manual of Systematic Bacteriology, $8^{\text {th }}$ Ed., Vol. 1. (Krieg, N. R., \& Holt, J. G. eds.). Pp. 220-229. Williams \& Wilkins Co., Baltimore.

Watanabe, T., Osaki, M., Yoshihara, T. \& Tadano, T. 1998a. Distribution and chemical speciation of aluminum in the Al-accumulator plant, Melastoma malabathricum L. Plant and Soil 201: 165-173.

Watanabe, T., Osaki, M. \& Tadano, T. 1998b. Effects of nitrogen source and aluminum on growth of tropical tree seedlings adapted to low pH soils. Soil Science and Plant Nutrition 44: 655-666.

Received $5^{\text {th }}$ Mar. 2006

Accepted $19^{\text {th }}$ May 2006 